Удк 663.95:541.87

\title{
СОДЕРЖАНИЕ МИКРОЭЛЕМЕНТОВ И НИЗКОМОЛЕКУЛЯРНЫХ АНТИОКСИДАНТОВ В ЧАЕ
}

\author{
() О.Н. Немерешина" ${ }^{* 1}$ Н.Ф. Гусев ${ }^{2}$, А.В. Филиппова ${ }^{2}$ \\ ${ }^{1}$ Оренбургская государственная медицинская академия, ул. Советская, 6, \\ Оренбург, 460000 (Россия), e-mail: orgma@esoo.ru \\ ${ }^{2}$ Оренбургский государственный аграрный университет, ул. Челюскинцев, 18, \\ Оренбург, 460014 (Россия), e-mail: orensau@mail.ru
}

В статье приведены результаты анализа содержания микроэлементов (Cu, Ni, Mn, $\mathrm{Zn}, \mathrm{Mg}, \mathrm{Fe}, \mathrm{Cr}, \mathrm{Co}, \mathrm{Na}, \mathrm{Pb}, \mathrm{As}$, $\mathrm{Cd}, \mathrm{Hg}$ ) и антиоксидантов в популярных сортах и марках чая. Выявлены значительные отличия в уровнях содержания элементов в образцах чая. Показатели предельно допустимого уровня содержания кадмия и свинца не были превышены. Ртуть и мышьяк в образцах чая не обнаружены. Не установлена зависимость содержания элементов и антиоксидантов от сорта и марки чая. Выявлена корреляция между уровнем содержания некоторых элементов и антиоксидантов в чае и обоснована необходимость совместного анализа данных показателей при исследовании растений.

Ключевые слова: чай, Thea sinensis L., антиоксиданты, флавоноиды, таниды, аскорбиновая кислота, микроэлементы, тяжелые металлы.

\section{Введение}

Проводимые в настоящее время исследования в области нутрициологии свидетельствуют о значительных нарушениях в рационе питания населения России [1-3]. Отмечается дефицит витаминов, витаминоподобных веществ природного происхождения, макро- и микроэлементов [2]. Указанный дефицит становится причиной снижения общей резистентности организма к неблагоприятным факторам среды, нарушения функционирования антиоксидантной защиты, формирования иммунодефицитных состояний, развития хронических заболеваний и снижения эффективности лечебных мероприятий [3, 4].

В Концепции государственной политики в области здорового питания населения Российской Федерации четко обозначена необходимость ликвидации дефицита микронутриентов в пищевом рационе населения $[2,3]$. Специализированные пищевые продукты и биологически активные добавки к пище отнесены к важнейшим инструментам оптимизации питания и здоровья населения [5]. К биологически активным веществам пищевых продуктов относят многие природные компоненты: отдельные незаменимые аминокислоты, экзогенные пептиды, витамины, фитонциды, полифенолы, алкалоиды, гликозиды, органические кислоты, эфирные масла и некоторые другие соединения [4].

В последние десятилетия медицинской наукой получены сведения о биогенности целого ряда микроэлементов, которые ранее не рассматривались в качестве факторов, необходимых для жизнедеятельности [6]. В настоящее время для многих биологически активных веществ (БАВ) и микроэлементов изучены

Немерешина Ольга Николаевна - доцент кафедры биохимии, кандидат биологических наук, тел.: (3532) 77-61-03, e-mail: olga.nemerech@ rambler.ru Гусев Николай Федорович - доцент кафедры биоэкологии, доктор биологических наук, тел.: (3532) 77-52-30, e-mail: nikolajj-gusev19@ rambler.ru Филиппова Ася Вячеславовна - заведующая кафедрой биоэкологии, доктор биологических наук, тел.: (3532) 77-58-13, e-mail: kassio-67@ yandex.ru их физиологическая роль в организме и биохимические механизмы действия [7]. Следовательно, участие БАВ и микроэлементов в обмене веществ и необходимость их присутствия в рационе питания приобрели научное обоснование [8].

Несмотря на большое число исследований в области рационального питания, проблема оптимального обеспечения организма человека БАВ

\footnotetext{
* Автор, с которым следует вести переписку.
} 
и микроэлементами в России далека от полного разрешения [9]. Указанное справедливо и для жителей Волго-Уральского региона, где обеспечить полноценное питание в зимне-весенний период достаточно сложно по многим позициям. В этой связи следует отметить, что самым распространенным горячим напитком в зимний период является чай, содержащий целый комплекс БАВ и микроэлементов [6, 10-12].

История чая в России начинается с 1618 г., когда китайские послы в качестве подарка привезли царю Михаилу Федоровичу несколько сортов китайского чая. На сегодняшний день основной поставщик чая в Россию не Китай, а Индия (около 50\%), далее следуют Шри-Ланка (около 20), Китай, Индонезия и Кения. Объемы производства российского краснодарского чая крайне невелики. К настоящему времени в России преобладает потребление черного чая (около 94\%). Несмотря на популяризацию зеленого чая, на его долю приходится около $2 \%$ потребления, на долю ароматизированных сортов чая - примерно $4 \%$. Доля потребления листового чая в России составляет $73 \%$, гранулированного $-27 \%$.

Таксономия чайного куста неоднозначна, в связи с чем данное растение имеет целый ряд наименований: Thea sinensis L., Camellia sinensis L. (O. Ktze), Camellia thea Link. и Camellia theifera Griff. [1].

Многие исследователи [13-15] рассматривают чай в качестве профилактического и лечебного средства при целом ряде заболеваний. Природные флавоноиды, таниды и фенолкарбоновые кислоты, содержащиеся в листьях чая, проявляют выраженную антиоксидантную активностью и способны эффективно обезвреживать свободные радикалы в тканях человека, тем самым ингибируя перекисное окисление липидов (ПОЛ) $[9,13,16]$. Несмотря на многочисленные сведения о химическом составе чая, результатов сравнительного анализа химического состава товарных образцов чая в нашем регионе найти не удалось.

Цель исследования - изучение содержания микроэлементов и низкомолекулярных антиоксидантов в чае наиболее широко распространенных в торговой сети Волго-Уральского региона сортов и марок.

\section{Экспериментальная часть}

Для исследования нами отобраны 14 образцов чая, в которых определяли содержание химических элементов, аскорбиновой кислоты, дубильных веществ и флавоноидов. Исследования проводились на базе комплексной аналитической межкафедральной лаборатории Оренбургского государственного аграрного университета. Содержание антиоксидантов полифенольной природы определялось методом высокоэффективной жидкостной хроматографии [17]. Определение элементного состава образцов чая проводилось методом атомной-абсорбционной спектрометрии [18]. Наличие и количественное содержание аскорбиновой кислоты в исследуемых образцах чая определяли методами, принятыми в биохимии [19].

Объектами нашего исследования выбраны сорта чая, пользующиеся широкой популярностью у местного населения: 1) Чай черный байховый пакетированный «Беседа»; 2) Чай зеленый пакетированный китайский «Зеленый дракон»; 3) Чай зеленый байховый пакетированный китайский «Акбар»; 4) Чай зеленый пакетированный «Ахмад»; 5) Чай черный байховый пакетированный «Принцесса Нури»; 6) Чай черный байховый гранулированный первого сорта «Золотая чаша»; 7) Чай зеленый байховый листовой «Ахмад»; 8) Чай черный байховый крупнолистовой «Принцесса Нури» Пекое; 9) Чай черный байховый крупнолистовой цейлонский «Ристон»; 10) Чай черный байховый мелколистовой цейлонский «Ристон»; 11) Чай зеленый крупнолистовой развесной «Сен-ча» (Тайвань); 12) Чай черный крупнолистовой «Howery orange Pekoe» - «Цейлонский щеголь»; 13) Чай черный крупнолистовой индийский «Dilmah»; 14) Чай черный крупнолистовой байховый «Акбар».

На первом этапе исследования нами проведен анализ содержания в образцах чая микроэлементов ( $\mathrm{Cu}, \mathrm{Ni}, \mathrm{Mn}, \mathrm{Zn}, \mathrm{Mg}, \mathrm{Fe}, \mathrm{Cr}, \mathrm{Co}, \mathrm{Na})$ и фитотоксичных элементов ( $\mathrm{Pb}, \mathrm{As}, \mathrm{Cd}, \mathrm{Hg})$.

Установлено, что содержание меди в исследуемых образцах чая составляет от 0,04 до 0,17 мг/кг (табл. 1, рис. 1). Лидируют по содержанию меди сорт чая «Золотая чаша» черный гранулированный и «Принцесса Нури» черный крупнолистовой. Чай черный крупнолистовой байховый «Акбар» отличается от исследуемых образцов самым низким содержанием меди. Зависимости содержания данного микроэлемента от сорта и марки чая не прослеживается (рис. 1), хотя известно, что данный микроэлемент играет важную ролью в метаболизме, так как входит в состав активных центров целого ряда важнейших ферментов подкласса оксидаз [20].

Содержание никеля в исследуемых образцах колебалось от 0,04 до 0,38 мг/кг (табл. 2, рис. 1) и также не указывает на зависимость от сорта чая. Максимальным содержанием никеля характеризуются сорта чая «Беседа» черный пакетированный $(0,38$ мг/кг) и чай «Принцесса Нури» черный крупнолистовой $(0,36$ мг/кг). Самое низкое содержание никеля отмечено в сортах черного крупнолистового чая марок «Акбар» и «Цейлонский щеголь». 
Таблица 1. Содержание элементов в образцах чая, мг/кг

\begin{tabular}{|c|c|c|c|c|c|c|c|c|c|c|c|c|c|c|}
\hline $\begin{array}{l}\text { № } \\
\Pi / \Pi\end{array}$ & Сорт чая & $\mathrm{Cu}$ & $\mathrm{Ni}$ & $\mathrm{Mn}$ & $\mathrm{Zn}$ & $\mathrm{Mg}$ & $\mathrm{Fe}$ & $\mathrm{Cr}$ & Co & $\mathrm{Cd}$ & $\mathrm{Pb}$ & As & $\mathrm{Na}$ & $\mathrm{Hg}$ \\
\hline 1 & $\begin{array}{l}\text { Черный пакетированный } \\
\text { байховый «Беседа» }\end{array}$ & 0,16 & 0,38 & 0,20 & 4,01 & 3,41 & 5,60 & 0,15 & 0,07 & 0,07 & 0,13 & 0 & 0,42 & 0 \\
\hline 2 & $\begin{array}{l}\text { Зеленый пакетированный } \\
\text { китайский «Зеленый } \\
\text { дракон» }\end{array}$ & 0,10 & 0,25 & 0,11 & 4,78 & 3,01 & 0,61 & 0,17 & 0,09 & 0,08 & 0,06 & 0 & 1,61 & 0 \\
\hline 3 & $\begin{array}{l}\text { Зеленый пакетированный } \\
\text { байховый китайский } \\
\text { «Акбар» }\end{array}$ & 0,13 & 0,12 & 0,12 & 5,60 & 1,00 & 4,30 & 0,10 & 0,02 & 0,01 & 0,04 & 0 & 0,20 & 0 \\
\hline 4 & $\begin{array}{l}\text { Зеленый пакетированный } \\
\text { «Ахмад» }\end{array}$ & 0,04 & 0,08 & 0,13 & 1,23 & 0,90 & 1,72 & 0,02 & 0,04 & 0,08 & 0,08 & 0 & 0,80 & 0 \\
\hline 5 & $\begin{array}{l}\text { Черный пакетированный } \\
\text { байховый «Принцесса } \\
\text { Нури» }\end{array}$ & 0,14 & 0,26 & 0,15 & 4,23 & 1,11 & 7,02 & 0,11 & 0,02 & 0,13 & 0,07 & 0 & 0,20 & 0 \\
\hline 6 & $\begin{array}{l}\text { Черный гранулирован- } \\
\text { ный байховый индий- } \\
\text { ский «Золотая чаша» }\end{array}$ & 0,17 & 0,15 & 0,13 & 3,42 & 0,60 & 6,32 & 0,11 & 0,02 & 0,01 & 0,05 & 0 & 0,12 & 0 \\
\hline 7 & $\begin{array}{l}\text { Зеленый листовой бай- } \\
\text { ховый «Ахмад» }\end{array}$ & 0,11 & 0,24 & 0,12 & 5,50 & 2,62 & 6,75 & 0,15 & 0,09 & 0,07 & 0,07 & 0 & 1,21 & 0 \\
\hline 8 & $\begin{array}{l}\text { Черный крупнолистовой } \\
\text { байховый «Принцесса } \\
\text { Нури» }\end{array}$ & 0,16 & 0,36 & 0,16 & 3,01 & 2,61 & 4,33 & 0,12 & 0,06 & 0,06 & 0,13 & 0 & 0,61 & 0 \\
\hline 9 & $\begin{array}{l}\text { Черный крупнолистовой } \\
\text { байховый цейлонский } \\
\text { «Ристон» }\end{array}$ & 0,14 & 0,20 & 0,14 & 3,84 & 1,01 & 7,42 & 0,10 & 0,01 & 0,01 & 0,06 & 0 & 0,23 & 0 \\
\hline 10 & $\begin{array}{l}\text { Черный мелколистовой } \\
\text { байховый «Ристон» }\end{array}$ & 0,14 & 0,25 & 0,14 & 5,73 & 2,78 & 5,35 & 0,14 & 0,07 & 0,07 & 0,08 & 0 & 0,90 & 0 \\
\hline 11 & $\begin{array}{l}\text { Зеленый крупнолистовой } \\
\text { развесной «Сен-ча» } \\
\text { (Тайвань) }\end{array}$ & 0,13 & 0,34 & 0,12 & 5,11 & 0,70 & 4,12 & 0,17 & 0,02 & 0,07 & 0,13 & 0 & 0,40 & 0 \\
\hline 12 & $\begin{array}{l}\text { Черный крупнолистовой } \\
\text { «Howery orange Pekoe»- } \\
\text { «Цейлонский щеголь» }\end{array}$ & 0,07 & 0,05 & 0,02 & 1,01 & 0,14 & 2,01 & 0,06 & 0,06 & 0,01 & 0,01 & 0 & 0,80 & 0 \\
\hline 13 & $\begin{array}{l}\text { Черный крупнолистовой } \\
\text { индийский «Dilmah» }\end{array}$ & 0,11 & 0,09 & 0,03 & 1,04 & 0,11 & 2,00 & 0,02 & 0,02 & 0,02 & 0,01 & 0 & 0,58 & 0 \\
\hline 14 & $\begin{array}{l}\text { Черный крупнолистовой } \\
\text { байховый «Акбар» }\end{array}$ & 0,04 & 0,04 & 0,02 & 1,03 & 0,11 & 3,10 & 0,04 & 0,03 & 0,02 & 0,01 & 0 & 0,67 & 0 \\
\hline
\end{tabular}

Демонстрируют существенное различие уровни содержания эссенциального элемента марганца в исследованных образцах чая - от 0,02 до 0,20 мг/кг (табл. 1, рис. 1). Максимальное содержание марганца отмечено в черном чае в пакетиках «Беседа» $(0,20$ мг/кг).

Максимальное содержание цинка обнаружено в черном мелколистовом байховом чае «Ристон»5,73 мг/кг, чуть меньшее количество цинка содержит чай черный байховый пакетированный «Принцесса Нури», минимальное - в черном крупнолистовом «Цейлонский щеголь» - 1,01 мг/кг (табл. 1, рис. 2).

Максимальное содержание магния отмечается в чае черном пакетированном «Беседа» $(3,41$ мг/кг) и зеленом пакетированном «Зеленый дракон» (3,01 мг/кг). Минимальным содержанием магния (0,01 мг/кг) характеризуются сорта черный крупнолистовой «Цейлонский щеголь», черный крупнолистовой «Dilmah», черный крупнолистовой«Акбар» (табл. 1, рис. 2).

Максимальное содержание железа отмечено в черном крупнолистовом цейлонском чае «Ристон»7,42 мг/кг, черном пакетированном «Принцесса Нури» - 7,02 мг/кг и зеленом листовом «Ахмад»6,42 мг/кг. Самым низким содержанием железа характеризуется зеленый пакетированный китайский чай «Зеленый дракон»-0,61 мг/кг (табл. 1, рис. 2).

Концентрация кобальта в различных сортах чая колеблется в интервале от 0,01 до 0,09 мг/кг (табл. 1, рис. 3): максимальное содержание кобальта отмечено в сортах зеленого чая: зеленый пакетированный китайский «Зеленый дракон» и зеленый листовой «Ахмад»; минимальное - в сортах черного чая: крупнолистовой цейлонский «Ристон» и гранулированный индийский «Золотая чаша». 


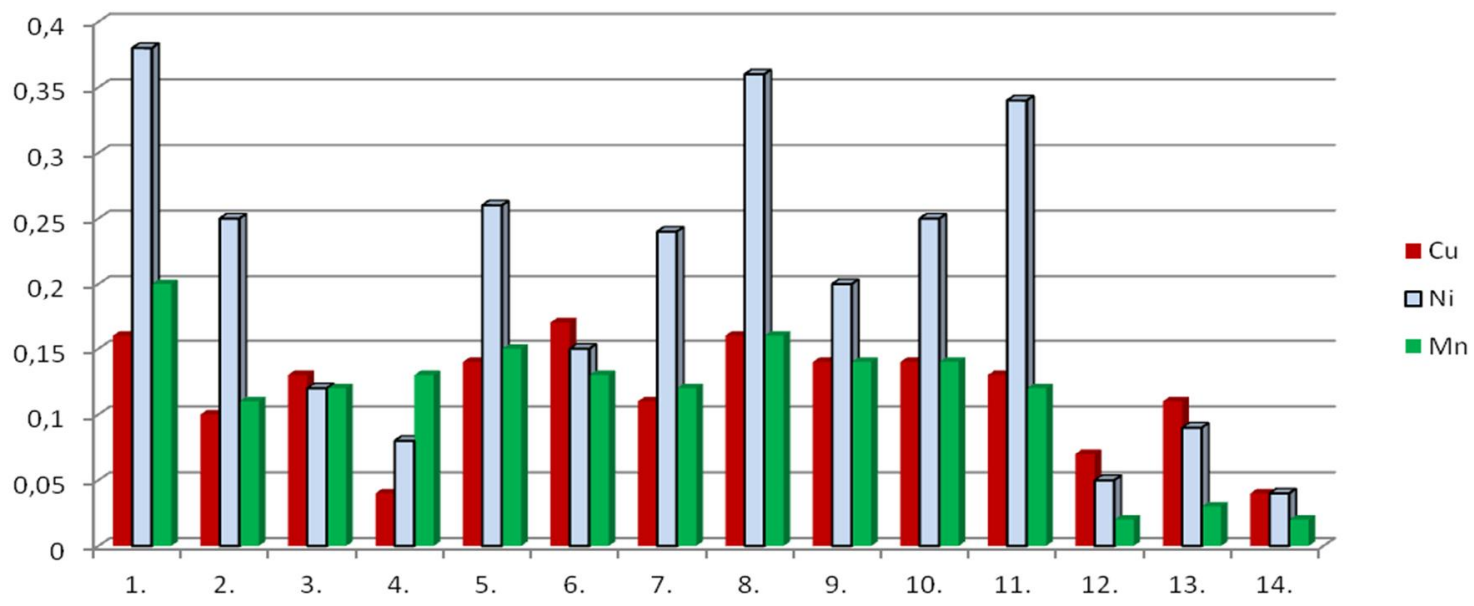

Рис. 1. Содержание микроэлементов $\mathrm{Cu}, \mathrm{Ni}, \mathrm{Mn}$ в образцах чая (мг/кг): 1) Чай черный байховый пакетированный «Беседа»; 2) Чай зеленый пакетированный китайский «Зеленый дракон»; 3) Чай зеленый байховый пакетированный китайский «Акбар»; 4) Чай зеленый пакетированный «Ахмад»; 5) Чай черный байховый пакетированный «Принцесса Нури»; 6) Чай черный байховый гранулированный первого сорта «Золотая чаша»; 7) Чай зеленый байховый листовой «Ахмад»; 8) Чай черный байховый крупнолистовой «Принцесса Нури» Пекое; 9) Чай черный байховый крупнолистовой цейлонский «Ристон»; 10) Чай черный байховый мелколистовой цейлонский «Ристон»; 11) Чай зеленый крупнолистовой развесной «Сен-ча» (Тайвань); 12) Чай черный крупнолистовой «Нowery orange Pekoe» - «Цейлонский щеголь»; 13) Чай черный крупнолистовой индийский «Dilmah»; 14) Чай черный крупнолистовой байховый «Акбар»

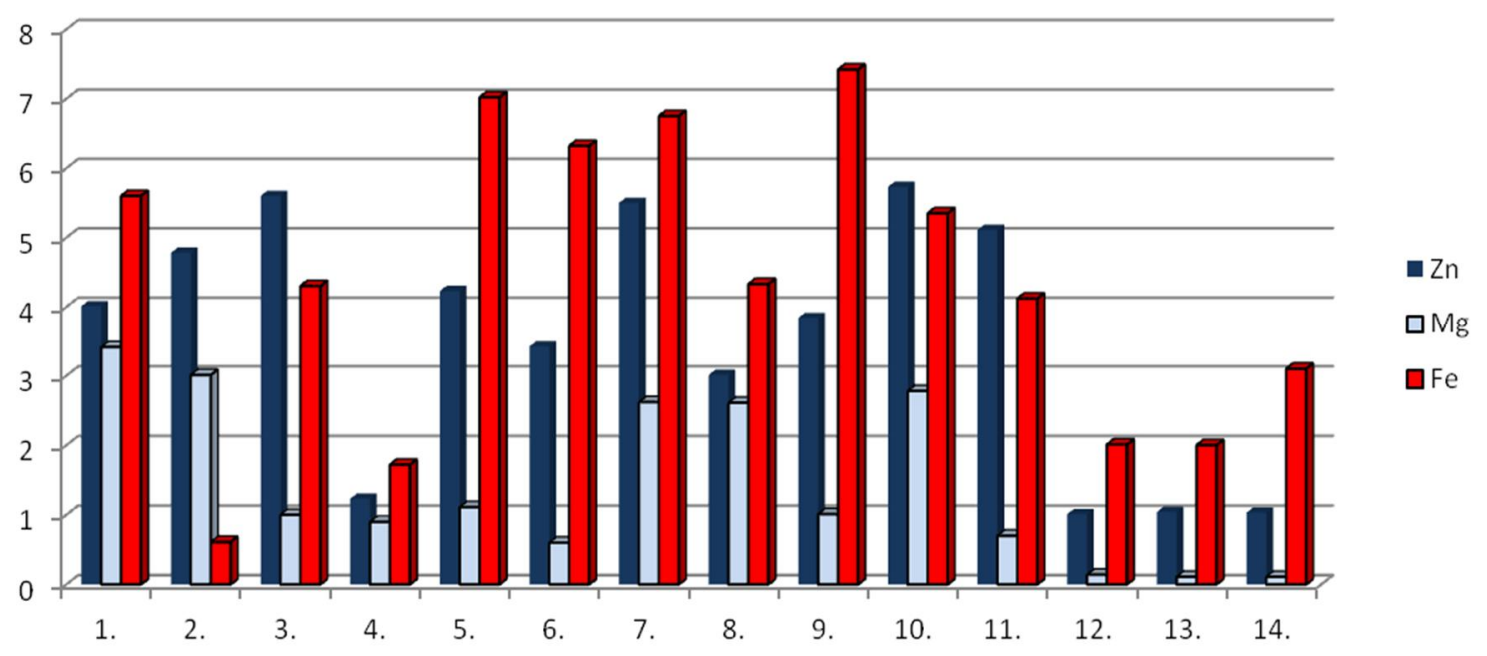

Рис. 2. Содержание микроэлементов $\mathrm{Zn}, \mathrm{Fe}, \mathrm{Mg}$ в образцах чая (мг/кг) (обозначение см. на рис. 1)

Самое высокое содержание хрома наблюдалось нами в сортах чая: зеленый пакетированный «Зеленый дракон» $(0,17$ мг/кг), черный пакетированный «Беседа» $(0,15$ мг/кг) и зеленый листовой «Ахмад» $(0,15$ мг/кг). Минимальное содержание хрома зафиксировано в черном крупнолистовом цейлонском чае «Ристон» $(0,01$ мг/кг), черном крупнолистовом индийском чае «Dilmah», зеленом крупнолистовом чае «Сен-ча» и зеленом пакетированном чае «Ахмад» $(0,02$ мг/кг).

Максимальное содержание натрия отмечено в зеленом китайском чае в пакетиках марки «Зеленый дракон» - 1,61 мг/кг (табл. 1, рис. 4). Минимальным содержанием натрия отличается гранулированный черный чай индийского производства «Золотая чаша» $(0,12$ мг/кг). 
Наибольшее содержание свинца отмечено в сортах чая «Беседа» черный байховый пакетированный, «Принцесса Нури» черный байховый крупнолистовой и сорте «Сен-ча» зеленом крупнолистовом 0,13 мг/кг (табл. 1, рис. 5). Самое низкое содержание свинца характерно для сортов: «Цейлонский щеголь» черный крупнолистовой, «Dilmah» черный крупнолистовой, «Акбар» черный крупнолистовой $(0,01$ мг/кг).

Наиболее высоким содержанием кадмия отличаются сорта чая: черный пакетированный «Принцесса Нури» $(0,13$ мг/кг), зеленый байховый листовой «Ахмад» $(0,08$ мг/кг), зеленый пакетированный китайский «Зеленый дракон» $(0,08$ мг/кг), зеленый пакетированный «Ахмад» (0,08 мг/кг). Минимальное содержание кадмия $(0,01$ мг/кг) установлено в образцах чая «Акбар» зеленый байховый пакетированный, «Ристон» черный крупнолистовой цейлонский, «Цейлонский щеголь» черный крупнолистовой (табл. 1, рис. 5).

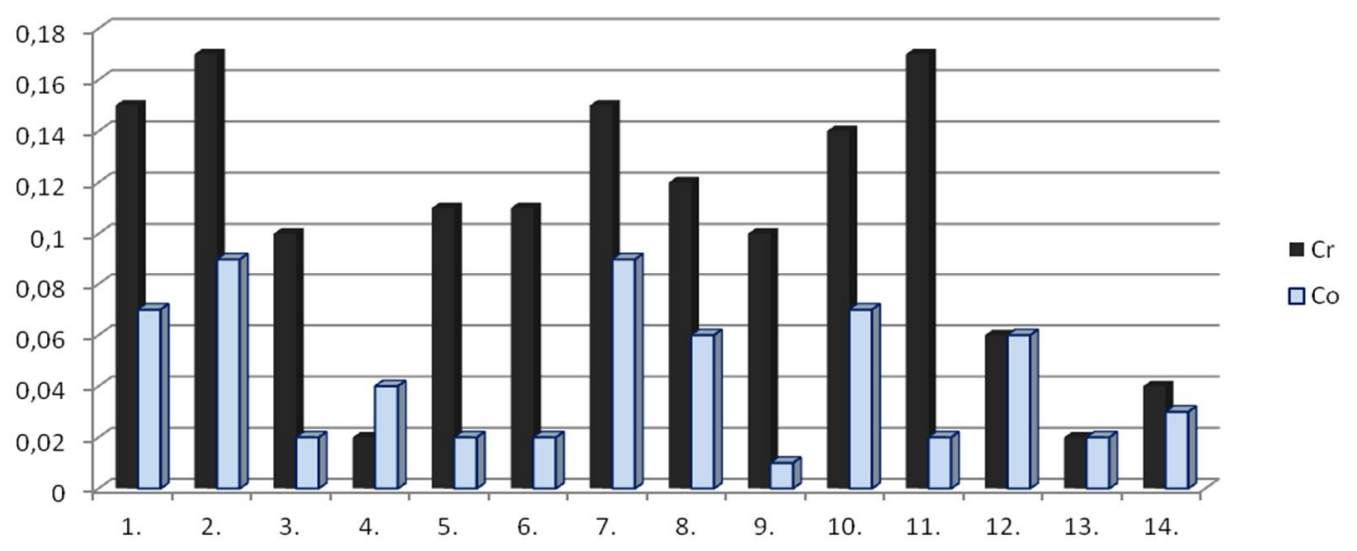

Рис. 3. Содержание микроэлементов Со, $\mathrm{Cr}$ в образцах чая (мг/кг) (обозначение см. на рис. 1)

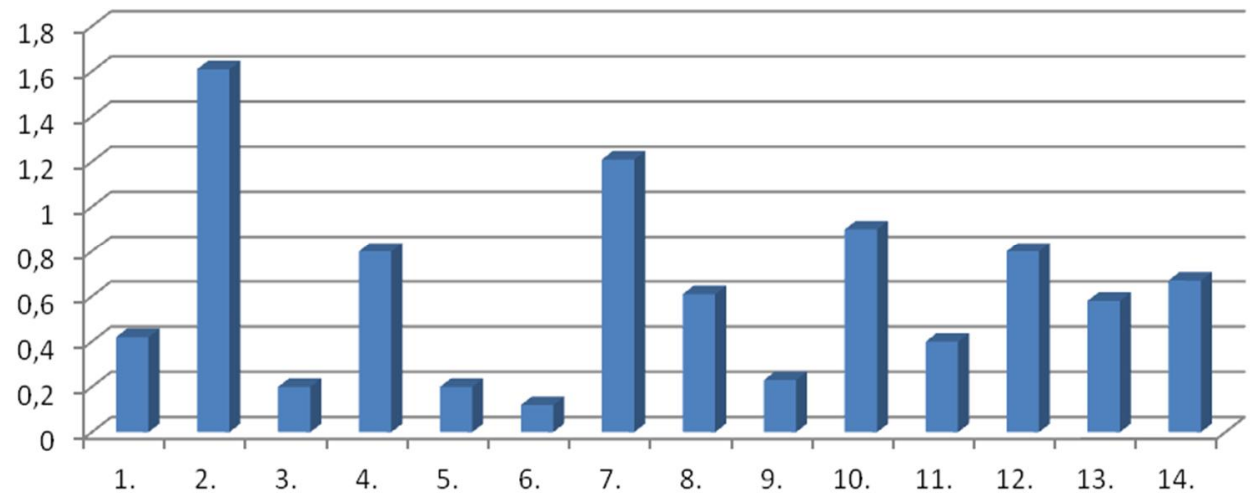

Рис. 4. Содержание Na в образцах чая (мг/кг) (обозначение см. на рис. 1)

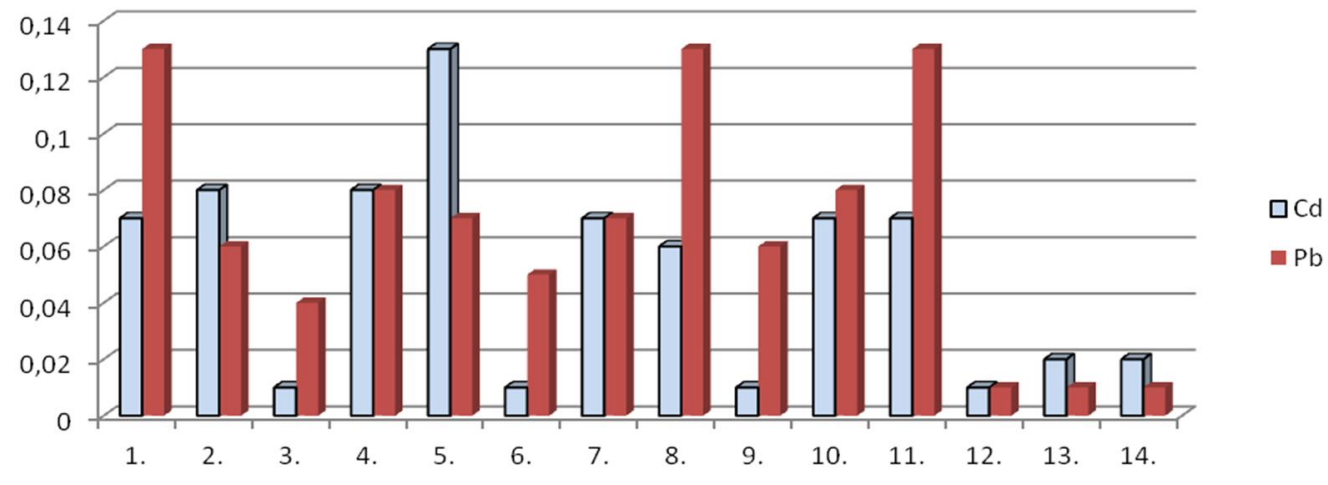

Рис. 5. Содержание токсичных элементов $\mathrm{Pb}, \mathrm{Cd}$ в образцах чая (мг/кг) (обозначение см. на рис. 1) 
На втором этапе исследований проведен анализ содержания в образцах чая низкомолекулярных водорастворимых антиоксидантов - полифенольных соединений (флавоноидов и танидов) и аскорбиновой кислоты (табл. 2, рис. 6).

Самым высоким содержанием аскорбиновой кислоты отличаются сорта: черный гранулированный байховый индийский чай «Золотая чаша» $(20,3 \pm 0,4$ мг/кг), черный крупнолистовой байховый чай «Акбар» $(20,2 \pm 0,4$ мг/кг) и зеленый листовой байховый чай «Ахмад» $(19,5 \pm 0,2 \mathrm{Mг} / к г)$.

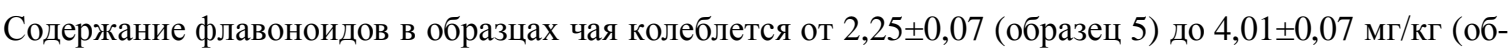
разец 13).

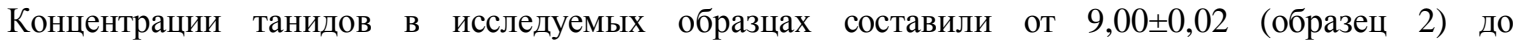
16,47士0,05 мг/кг (образец 14).

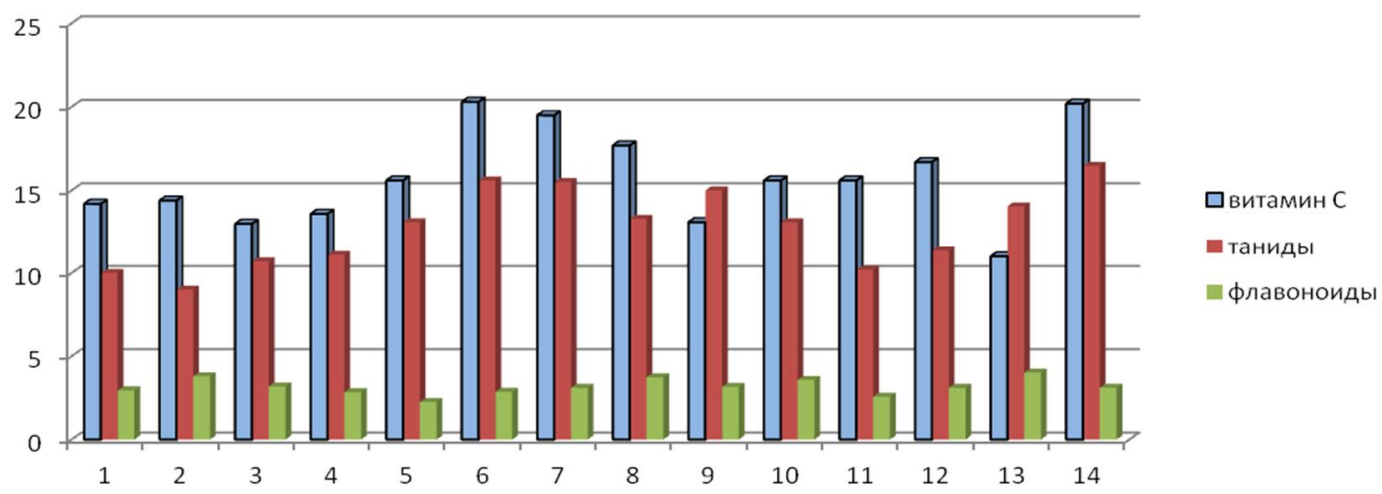

Рис. 6. Содержание витамина $\mathrm{C}$, танидов и флавоноидов в образцах чая (обозначение см. на рис. 1)

Таблица 2. Содержание антиоксидантов в образцах чая, мг/кг

\begin{tabular}{|c|c|c|c|c|}
\hline \multirow{2}{*}{$\begin{array}{l}\text { № } \\
\text { ח/ח }\end{array}$} & \multirow{2}{*}{ Сорта чая } & \multicolumn{3}{|c|}{ Содержание антиоксидантов (мг/кг) } \\
\hline & & витамин C & флавоноиды & таниды \\
\hline 1 & Черный пакетированный байховый «Беседа» & $14,2 \pm 0,1$ & $2,95 \pm 0,05$ & $10,10 \pm 0,04$ \\
\hline 2 & $\begin{array}{l}\text { Зеленый пакетированный китайский «Зеленый } \\
\text { дракон» }\end{array}$ & $14,4 \pm 0,3$ & $3,80 \pm 0,04$ & $9,00 \pm 0,02$ \\
\hline 3 & $\begin{array}{l}\text { Зеленый пакетированный байховый китайский } \\
\text { «Акбар» }\end{array}$ & $13,0 \pm 0,2$ & $3,19 \pm 0,04$ & $10,70 \pm 0,03$ \\
\hline 4 & Зеленый пакетированный Ахмад» & $13,6 \pm 0,2$ & $2,84 \pm 0,05$ & $11,06 \pm 0,04$ \\
\hline 5 & $\begin{array}{l}\text { Черный пакетированный байховый «Принцесса } \\
\text { Нури» }\end{array}$ & $15,6 \pm 0,2$ & $2,25 \pm 0,07$ & $13,10 \pm 0,03$ \\
\hline 6 & $\begin{array}{l}\text { Черный гранулированный байховый индийский } \\
\text { «Золотая чаша» }\end{array}$ & $20,3 \pm 0,4$ & $2,86 \pm 0,05$ & $15,60 \pm 0,04$ \\
\hline 7 & Зеленый листовой байховый «Ахмад» & $19,5 \pm 0,2$ & $3,09 \pm 0,04$ & $15,50 \pm 0,04$ \\
\hline 8 & $\begin{array}{l}\text { Черный крупнолистовой байховый «Принцесса } \\
\text { Нури» }\end{array}$ & $17,7 \pm 0,3$ & $3,73 \pm 0,04$ & $13,03 \pm 0,03$ \\
\hline 9 & $\begin{array}{l}\text { Черный крупнолистовой байховый цейлонский } \\
\text { «Ристон» }\end{array}$ & $13,1 \pm 0,2$ & $3,16 \pm 0,06$ & $15,01 \pm 0,04$ \\
\hline 10 & Черный мелколистовой байховый «Ристон» & $15,6 \pm 0,3$ & $3,57 \pm 0,04$ & $13,14 \pm 0,06$ \\
\hline 11 & $\begin{array}{l}\text { Зеленый крупнолистовой развесной «Сен-ча» } \\
\text { (Тайвань) }\end{array}$ & $15,6 \pm 0,4$ & $2,57 \pm 0,06$ & $10,18 \pm 0,03$ \\
\hline 12 & $\begin{array}{l}\text { Черный крупнолистовой цейлонский «Howery } \\
\text { orange Pekoe» - «Цейлонский щеголь» }\end{array}$ & $16,7 \pm 0,3$ & $3,10 \pm 0,04$ & $11,36 \pm 0,04$ \\
\hline 13 & Черный крупнолистовой индийский «Dilmah» & $11,0 \pm 0,2$ & $4,01 \pm 0,07$ & $14,05 \pm 0,05$ \\
\hline 14 & Черный крупнолистовой байховый «Акбар» & $20,2 \pm 0,4$ & $3,11 \pm 0,04$ & $16,47 \pm 0,05$ \\
\hline
\end{tabular}

\section{Обсуждение результатов}

Химический состав чайного листа и самого напитка содержит сложный комплекс веществ первичного и вторичного синтеза и микроэлементов $[6,16,21]$. 
Принято считать, что преобладание в составе золы растворимых в воде минеральных веществ положительно сказывается на качестве чая. По мере старения листьев содержание минеральных веществ повышается. Основными макроэлементами чая являются калий, фосфор, кальций и магний. В золе чая также содержатся медь, калий, кальций, магний, натрий, железо, кремний, алюминий, марганец, стронций, никель, цинк, барий, титан, хром, олово, серебро, ванадий, фтор, йод и другие важные микроэлементы [11]. Содержание минеральных веществ в листьях чая составляет около 4-5\% в заварке и 5-6\% в готовом напитке [11]. Минеральные вещества, содержащиеся в чае, способны переходить в водный раствор при приготовлении отваров в среднем на 50-60\% [6, 21]. Для некоторых элементов степень их извлечения водой при приготовлении отваров достигает 90-95\%, т.е. отвар обогащен необходимыми организму человека микро- и макроэлементами [15].

В соответствии с СанПиН 2.3.2.1078-01 «Гигиенические требования безопасности и пищевой ценности пищевых продуктов» [22], в чае определены предельно допустимые уровни ртути, мышьяка, свинца и кадмия, остальные ТМ в чае не регламентируются, что представляет трудность в определении гигиенически безопасного содержания их для человека (табл. 3). Все исследуемые образцы чая соответствовали нормам СанПиН.

Функции микроэлементов в организме растений и животных разнообразны. Роль многих биогенных элементов доказана, а для некоторых предполагается их участие в работе ферментов в роли как активаторов, так и компонентов активного центра и кофакторов (например, в составе гема).

Так, известно, что ионы меди входят в состав активных центров целого ряда важнейших ферментов подкласса оксидаз [20]: полифенолоксидаз, аскорбатоксидазы и других ферментов фотосинтеза [7]. В организме человека медь оказывает влияние на процессы кроветворения, работу желез внутренней секреции, воздействует на функции яичников [4], способствует усвоению витамина С. В то же время повышенные концентрации меди оказывают цитотоксическое и генотоксическое действие, так как являются радикалоинициирующим фактором. Суточная потребность в меди составляет для взрослого человека около 1-2 мг. Из числа исследуемых образцов лидирует по содержанию меди крупнолистовой черный чай «Принцесса Нури» $(0,16$ мг/кг). Пониженным содержанием меди отличаются черный крупнолистовой чай «Акбар» и зеленый чай в пакетиках «Ахмад» $(0,04$ мг/кг).

Никель оказывает неспецифическое действие на целый ряд металлоферментов, участвуя тем самым во многих биохимических реакциях. Никель активирует аргиназу, оксалоацетатдекарбоксилазу, трансаминазы, ускоряет окисление сульфгидридных групп в дисульфидные, ингибирует фосфатазу, стабилизирует работу трансляционного аппарата, стимулирует синтез антоцианов [4]. Значительные количества никеля отмечаются в цветках флавоноидсодержащих растений [13]. Суточная потребность человека в никеле в зависимости от возраста, пола и веса составляет около 100-300 мкг. Дефицит никеля в питании приводит к замедлению роста, нарушению остеогенеза, снижению концентрации глюкозы в крови, изменениям состояния мембран, нарушениям обмена кальция, железа и витамина $\mathrm{B}_{12}$. Повышенные концентрации никеля могут способствовать усилению перекисного окисления липидов мембран [7]. Уровни содержания никеля в образцах чая находятся в интервале от 0,04 до 0,38 мг/кг (табл. 1, рис. 1) и не зависят от сорта. Самые низкие концентрации никеля отмечены в образцах крупнолистового черного чая под номерами 12, 13 и 14 (табл. 1, рис. 1).

Марганец является биогенным элементом, входящим в состав многих металлофлавопротеидов, принимающих участие в окислительно-восстановительных процессах (фотосинтез, гликолиз, цикл трикарбоновых кислот) [7]. В растениях марганец активирует ферменты биосинтеза углеводов, стероидов, танидов, алкалоидов, аскорбиновой кислоты и витамина $\mathrm{B}_{2}$ [23], принимает участие в процессах дыхания, фотосинтеза, азотфиксации, отвечает за окисление железа. Суточная потребность человека в марганце составляет 5-10 мг. В организме человека марганец участвует в процессе остеогенеза, реакциях иммунитета, процессах кроветворения и тканевого дыхания, а также в реакциях общего обмена. При дефиците марганца наблюдаются резкая потеря веса, тошнота, изменение цвета волос, возможен остеопороз. Максимальным содержание марганца отмечено в чае «Беседа» черный пакетированный $(0,20$ мг/кг). Минимальное содержание марганца характерно для образцов крупнолистового черного чая под номерами 12, 13 и 14 (табл. 1, рис. 1).

Таблица 3. Нормирование тяжелых металлов в чае

\begin{tabular}{c|c|c|c|c}
\hline Токсичный элемент & Свинец & Кадмий & Мышьяк & Ртуть \\
\hline Допустимые уровни, мг/кг, не более & 10,0 & 1,0 & 1,0 & 0,1 \\
\hline
\end{tabular}


Цинк входит в состав активных центров целого ряда ферментов (в частности, ферментов синтеза полифенолов) [7, 24]. Цинк повышает устойчивость растений к засухе и гипертермии [7]. Суточная потребность в цинке оставляет окло 10-25 мг. В организме человека цинк принимает участие в реакциях общего обмена, остеогенезе, сахаро-инсулиновом обмене, синтезе белков и нуклеиновых кислот, необходим для нормального функционирования половой системы. Для высоких концентраций цинка установлено генотоксическое действие. Самые низкие концентрации цинка характерны для образцов крупнолистового черного чая под номерами 12, 13 и 14, а также зеленого чая в пакетиках «Ахмад» (табл. 1, рис. 2).

Магний является активатором более 300 ферментов, участвующих в процессах метаболизма [4]. Магний является s-элементом и не входит в число так называемых «тяжелых металлов». В организме человека магний обладает общеукрепляющим действием, влияет на работу сердечно-сосудистой системы, способствует передаче нервных импульсов, оказывает спазматическое и сосудорасширяющее действие, стимулирует перистальтику, повышает отделение желчи и способствует поддержанию кислотно-щелочного баланса. Суточная потребность в магнии в среднем составляет около 400 мг. Самые низкие концентрации магния характерны для трех образцов крупнолистового черного чая под номерами 12,13 и 14 (табл. 1, рис. 2).

В числе изучаемых нами микроэлементов не относится к числу «тяжелых металлов» s-элемент натрий. В живых организмах ионы натрия способствуют поддержанию водно-электролитного равновесия. Содержание натрия в организме растений составляет в среднем $0,02 \%$. Ионы натрия принимают участие в транспорте веществ через мембраны с помощью так $\mathrm{Na}^{+} / \mathrm{K}^{+}$АТФазы. Нами не обнаружено зависимости концентрации натрия от сорта чая.

Железо входит в состав ферментов растений, принимающих участие во многих окислительновосстановительных реакциях. Доказана роль железа в процессах фотосинтеза, тканевого дыхания, синтеза хлорофилла, метаболизме серы и азота $[1,25]$. Дефицит железа в растениях приводит к хлорозу листьев и даже отмиранию молодых побегов. В организме человека железо содержится в структуре многих сложных белков: гемоглобина, миоглобина, цитохромов, пероксидаз. Суточная потребность организма взрослого человека в железе составляет от 10 до 30 мг. Дефицит железа - один из самых распространенных форм гипомикроэлементозов человека. Самые низкие концентрации железа отмечены в зеленом чае в пакетиках «Зеленый дракон» и в образцах крупнолистового черного чая под номерами 12, 13 и 14 (табл. 1, рис. 2).

Кобальт принимает участие в фосфорилировании, входит в состав витамина $\mathrm{B}_{12}$ и некоторых других кислородсвязывающих соединений, активирует ферменты симбиотической азотфиксации и, таким образом, связан с биосинтезом аминокислот и алкалоидов. Высказываются предположения о стимулировании этим элементом процесса оплодотворения [4]. В организме человека и животных ионы кобальта принимают участие в кроветворении, в обмене железа, углеводов, липидов [7]. Кобальт является коферментом рибонуклеозидтрифосфатредуктазы, метилтрансферазы, аденилатциклазы, аргиназы и других ферментов $[7,21]$. Есть сведения о влиянии кобальта на функцию щитовидной железы, состояние миокарда [4]. Суточная потребность взрослого человека в кобальте в среднем составляет около 0,1-0,2 мг. Содержание кобальта в сортах чая колеблется в интервале от 0,01 до 0,09 мг/кг (табл. 1, рис. 3).

Физиологическая роль хрома в растениях изучена недостаточно, предполагается его участие в фотосинтезе и продуцировании флавоноидов [4]. В организме человека хром принимает участие в регуляции обмена углеводов и является компонентом низкомолекулярного органического комплекса - фактора толерантности к глюкозе. Дефицит хрома может быть причиной диабетоподобного состояния. Суточная норма хрома в питании взрослого человека составляет в среднем $0,2-0,25$ мг. Дефицит хрома приводит к задержке роста, нарушениям высшей нервной деятельности, снижению оплодотворяющей способности сперматозоидов [7]. Минимальное содержание хрома зафиксировано в крупнолистовом черном чае «Dilmah» и зеленом чае в пакетиках «Ахмад» (табл. 1, рис. 3).

Большая часть вышеперечисленных микроэлементов относится экологами к группе так называемых «тяжелых металлов». Употребление терминов «токсические элементы», «тяжелые металлы» и «микроэлементы» связано в основном с их концентрацией в организмах и окружающей среде $[22,26]$. При этом загрязнение среды тяжелыми металлами является приоритетной проблемой, которая с каждым годом становится все более актуальной [27]. Кумуляция тяжелых металлов в пищевых растениях становится причиной развития различных заболеваний человека и животных [22].

Высокие концентрации тяжелых металлов оказывают негативное действие на клеточный метаболизм. Среди известных молекулярных механизмов токсического действия тяжелых металлов многие исследователи ставят на первое место образование активных форм кислорода, автоокисление и реакции Фентона (1) 
и Хабера - Вейса $(2,3)$. Данный механизм является типичным для металлов с переменной валентностью $(\mathrm{Cu}$, $\mathrm{Fe}, \mathrm{Mn}, \mathrm{Co}$ и другие) и приводит к образованию высокотоксичных гидроксильных радикалов [23]:

$$
\mathrm{Me}^{(\mathrm{n}-1)+}+\mathrm{H}_{2} \mathrm{O}_{2} \rightarrow \mathrm{Me}^{\mathrm{n}+}+\mathrm{HO}^{-}+\mathrm{HO}^{\circ}
$$

Восстановление металла обеспечивает супероксиданион:

$$
\mathrm{O}_{2} \cdot-\mathrm{Me}^{\mathrm{n}+} \rightarrow \mathrm{Me}^{(\mathrm{n}-1)+}+\mathrm{O}_{2}
$$

Цикл Хабера - Вейса представляет собой суммарную реакцию - восстановление пероксидов посредством супероксиданиона при участии металлов с переменой валентностью:

$$
\mathrm{O}_{2}{ }^{--}+\mathrm{H}_{2} \mathrm{O}_{2} \rightarrow \mathrm{O}_{2}+\mathrm{HO}^{-}+\mathrm{HO}^{\bullet}
$$

Гидроксильный радикал $\left(\mathrm{HO}^{\circ}\right)$, является мощным окислителем, неспособным к внутриклеточной миграции, так как мгновенно реагирует с биологическими молекулами, инициируя перекисное окисление липидов, разрушение мембран, деградацию белков, повреждение ДНК и РНК [15]. В растительных клетках нет ферментных систем, способных к нейтрализации гидроксильного радикала, что повышает роль неферментативного звена антиокислительной защиты [20].

Другим механизмом токсического действия тяжелых металлов является блокирование функциональных групп в биомолекулах (в основном сульфгидридных), эта реакция в основном характерна для таких редокс-неактивных тяжелых металлов, как кадмий и ртуть [11]. Действие на растения повышенных концентраций редокс-неактивных металлов также нередко приводит к повышению перекисного окисления липидов [11]. Для кадмия и некоторых других металлов установлена способность ингибировать антиоксидантные ферменты, особенно глутатионредуктазу [4, 11].

Свинец и кадмий считаются основными фитотоксикантами среди обнаруженным нами в чае тяжелых металлов, так как не относятся к биогенным и отличаются высокой токсичностью и темпами накопления в окружающей среде [4].

Свинец для растений менее токсичен, чем для человека и животных, так как его соединения малорастворимы, что снижает его биодоступность для растений. Токсическое действие свинца связывают с образованием устойчивых меркаптидов за счет взаимодействия ионов свинца и сульфгидридных групп SHсодержащих ферментов, что приводит к блокированию ферментных систем. В организме человека свинец влияет на биосинтез гемоглобина, нуклеиновых кислот, протеидов и гормонов. Свинец токсически воздействует на кроветворную, нервную и выделительную системы. При повышенном содержании свинца в организме животных и человека развиваются малокровие, общая слабость, туберкулез, происходит перерождение тканей, печени и почек [21]. Максимальным содержанием свинца из исследуемых образцов отличаются: чай «Принцесса Нури» черный крупнолистовой, черный чай в пактиеках «Беседа» и зеленый крупнолистовой чай «Сен-Ча» (табл. 1, рис. 5).

Опасным для жизнедеятельности растений и животных токсикантом является кадмий, активно нарушающий работу ферментных систем [21]. Кадмий легче, чем свинец, поглощается корневой системой и листьями растений. Для кадмия установлена способность ингибировать антиоксидантные ферменты, особенно глутатионредуктазу [7], вызывая повреждение клеточных мембран и ДНК. В гигиене питания человека кадмий считается одним из самых опасных токсикантов внешней среды - принятая внутрь доза 30-40 мг уже может оказаться смертельной. Период полувыведения кадмия составляет более 10 лет, поэтому возможно хроническое отравление этим элементом. Симптомы отравления - поражение почек и нервной системы с последующим возникновением острых костных болей, возможно также нарушение функции легких. Самое высокое содержание кадмия отмечено нами в зеленом чае в пакетиках марок «Зеленый дракон» и «Ахмад» (табл. 1, рис. 5).

Ввиду способности большинства исследуемых микроэлементов принимать участие в окислительных процессах живых клеток нами сделана попытка определить уровень содержания компонентов неферментативного звена антиоксидантной защиты чайного листа, что может предоставить дополнительный материал по механизмам клеточной адаптации и позволит пополнить сведения о содержании антиоксидантов в чае.

Чай, как и все высшие растения, отличается достаточно высокой толерантностью к воздействию повышенных концентраций тяжелых металлов. К механизмам устойчивости растений можно отнести задержку тяжелых металлов в подземных органах с помощью специальных белков металлотионеинов для 
защиты ассимилирующих и генеративных органов, а также выработку низкомолекулярных антиоксидантов (полифенолов, аскорбиновой кислоты, каротиноидов, токоферола и других соединений).

Производные фенолов играют важную роль в повышении стрессоустойчивости растений, и в целом ряде работ отмечается индукция синтеза полифенольных соединений под влиянием техногенных факторов $[13,16,24]$. Именно содержанием комплекса полифенольных соединений группы витамина Р в значительной мере определяется ценность зеленого чая. Поэтому важнейшим в биохимии чая является вопрос образования, превращения и условий накопления фенольных соединений [13]. Фенольные соединения составляют около 14-26\% от общего содержания экстрактивных веществ чая. Содержание их в чайном листе зависит от сорта растения, возраста листа, времени сбора, экологических факторов и системы агротехнических мероприятий [11].

Сильным Р-витаминным действием обладает чайный танин (12\% сухого веса), представляющий собой смесь катехинов и их галловых эфиров. Указанные вещества обладают высокой биологической активностью Р-витаминного типа: повышают прочность капилляров, уменьшают проницаемость стенок сосудов, способствуют лучшему усвоению аскорбиновой кислоты, являются сильными антиоксидантами [8], обладают радиопротекторным и антимикробным действием [27]. Сочетание витаминов С и Р чае усиливает сопротивляемость организма человека инфекционным заболеваниям.

Все исследуемые образцы чая отличаются высоким содержанием танидов: от 9,00 до 16,47 мг/кг (табл. 2, рис. 6).

По мнению ряда исследователей лекарственных растений, наибольший вклад в суммарную антиоксидантную активность водных извлечений вносят флавоноиды и фенолкарбоновые кислоты $[13,20,23,28]$. В чае обнаружено более 10 флавоноидов, в основном представленых гликозидами (кверцетин, кемпферол и др.), которые также обладают капилляроукрепляющими свойствами, как и таниды. При производстве зеленого чая фенольные соединения претерпевают слабое окисление, и их содержание больше, чем в черном чае. Поэтому считается, что Р-витаминные свойства у зеленого чая проявляются сильнее [24]. По результатам нашего исследования указанная зависимость не просматривается. Содержание флавоноидов в сортах чая колебалось в интервале от 2,25 до 4,01 мг/кг (табл. 2, рис. 6).

Содержание полифенольных антиоксидантов в клетках и тканях организмов способствует торможению процессов перекисного окисления липидов клеточных мембран, которое можно условно изобразить следующей принципиальной схемой [29]:

1. Образование $\mathrm{R}^{\cdot}$.

2. $\mathrm{R}^{\cdot}+\mathrm{O}_{2} \rightarrow \mathrm{RO}_{2}$.

3. $\mathrm{RO}_{2}^{\circ}+\mathrm{RH} \rightarrow \mathrm{ROOH}+\mathrm{R}^{\circ}$.

Фенольные соединения способны блокировать взаимодействие окисляющегося субстрата с перекисным радикалом и следовательно тормозить цепное окисление по схеме:

$$
\mathrm{PhOH}+\mathrm{RO}_{2}{ }^{*} \rightarrow \mathrm{PhO}^{*}+\mathrm{ROOH} .
$$

В результате при окислении фенолят-иона образуется феноксильный радикал, который претерпевает димеризацию с образованием связей углерод - углерод или углерод - кислород:

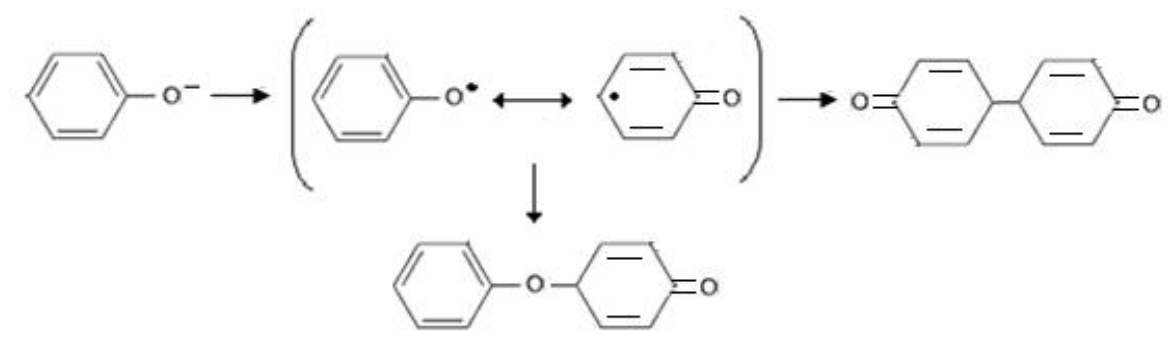

Феноксильные радикалы могут далее обезвреживаться глутатионпероксидазой по схеме:

$$
2 \mathrm{PhO}^{\circ}+2 \mathrm{HS}-\mathrm{G} \rightarrow 2 \mathrm{PhOH}+\mathrm{GS}-\mathrm{SG} .
$$

Таким образом, фенольные соединения (таниды и флавоноиды) в тканях растений и организме человека выполняют антиоксидантные (мембраностабилизирующие, цитозащитные) функции. 
Содержание аскорбиновой кислоты в экстрактивных веществах чая достигает 2-3\% [11]. Витамин С находится в чае в природном комплексе с железом, что облегчает его усвоение организмом человека. Содержащиеся в зеленом чае катехины предохраняют витамин С от окисления, повышая его сохранность в чае. Считается, что содержание витамина С в зеленом чае примерно в два раза больше, чем в черном, что связано с термическим воздействием при сушке и с окислительными процессами во время скручивания и ферментации [8].

Аскорбиновая кислота входит в число соединений, способствующих повышению устойчивости растений к неблагоприятным условиям среды обитания, что не в последнюю очередь обусловлено способность проявлять антиоксидантные свойства [21]:

$$
\begin{aligned}
& \mathrm{HO}-\text {-аск-OH }+\mathrm{R}-\mathrm{C}^{\bullet} \rightarrow \text { HO-аск-O }{ }^{\bullet}+\mathrm{R}-\mathrm{CH} ; \\
& 2 \text { HO-аск-O }+2 \text { HS-G } \rightarrow 2 \text { HO-аск-OH + GS-SG. }
\end{aligned}
$$

Содержание аскорбиновой кислоты в сортах чая находится в интервале от 11,0 до 20,3 мг/кг (табл. 2). Несколько пониженным содержанием витамина С характеризуются сорта чая в пакетиках (рис. 6).

Некоторые микроэлементы входят в активный центр или активируют ферменты, участвующие в биогенезе различных групп биологически активных веществ (в том числе полифенолов и аскорбиновой кислоты), отсюда их избирательное накопление растениями $[16,27]$. В биогенезе полифенольных соединений, обладающих цитозащитным мембраностабилизирующим действием, принимает участие группа флавопротеиновых ферментов, активируемых ионами меди, марганца, цинка и молибдена [16].

В условиях повышенного содержания тяжелых металлов в окружающей среде и тканях растений можно предполагать индукцию синтеза низкомолекулярных антиоксидантов, что связано с мембраностабилизирующим, цитозащитным действием указанных соединений в условиях окислительного стресса растений. С другой стороны - хорошая обеспеченность растений чая микроэлементами (медь, молибден, кобальт, цинк) может сама по себе способствовать индукции синтеза антиоксидантов группы полифенолов (флавоноидов, танидов, антоцианов, фенолкарбоновых кислот) и аскорбиновой кислоты.

Изучение содержания БАВ и химических элементов в различных сортах чая позволило нам просчитать корреляцию между содержанием 13 эссенциальных и токсических элементов и содержанием дубильных веществ, флавоноидов и аскорбиновой кислоты (табл. 4). Расчет корреляции содержания низкомолекулярных антиоксидантов и микроэлементов в исследуемых образцах чая указывает на выраженную положительную корреляцию между содержанием в растениях чая витамина С и микроэлементов хрома $(0,81)$, кобальта $(0,82)$, магния $(0,54)$ и натрия $(0,64)$.

По результатам исследований не удалось установить сколько-нибудь выраженную корреляцию между содержанием в образцах чая меди и низкомолекулярными антиоксидантами. Не выявлена корреляция между содержанием в чае никеля и хрома с содержанием флавоноидов и между содержанием марганца и кадмия с витамином С.

Для остальных микроэлементов уровни положительной корреляции колебались от 0,23 (цинк/аскорбат) до 0,47 (железо/таниды), уровни отрицательной корреляции - от -0,22 (натрий/таниды) до -0,45 (железо/флавоноиды; цинк/таниды).

Для токсичных элементов свинца и кадмия обнаружена положительная корреляция с содержанием аскорбиновой кислоты и отрицательная - с содержанием флавоноидов и танидов. Выраженная отрицательная корреляция $(-0,61)$ характерна лишь между содержанием кадмия и флавоноидами. Для остальных элементов корреляция выражена слабо (от 0,1 до 0,46).

Таблица 4. Корреляция содержания водорастворимых антиоксидантов и микроэлементов в чайном листе $(\mathrm{M} / \mathrm{K} \Gamma)$

\begin{tabular}{l|c|c|c|c|c|c|c|c|c|c|c}
\hline \multicolumn{1}{c|}{ Элементы } & $\mathrm{Zn}$ & $\mathrm{Ni}$ & $\mathrm{Cr}$ & $\mathrm{Cu}$ & $\mathrm{Pb}$ & $\mathrm{Mn}$ & $\mathrm{Co}$ & $\mathrm{Cd}$ & $\mathrm{Fe}$ & $\mathrm{Mg}$ & $\mathrm{Na}$ \\
\hline $\begin{array}{l}\text { Корреляция содержания } \\
\text { элемента и витамина C }\end{array}$ & 0,23 & 0,4 & 0,81 & $-0,15$ & 0,46 & $-0,12$ & 0,82 & 0,10 & 0,30 & 0,54 & 0,64 \\
$\begin{array}{l}\text { Корреляция содержания } \\
\text { элементов и флавоноидов }\end{array}$ & $-0,35$ & $-0,09$ & $-0,02$ & $-0,02$ & $-0,20$ & $-0,28$ & 0,56 & $-0,61$ & $-0,45$ & 0,25 & 0,48 \\
$\begin{array}{l}\text { Корреляция содержания } \\
\text { элементов и танидов }\end{array}$ & $-0,45$ & $-0,31$ & $-0,32$ & $-0,01$ & $-0,26$ & $-0,27$ & $-0,26$ & $-0,33$ & 0,47 & $-0,32$ & $-0,22$ \\
\hline
\end{tabular}




\section{Выводы}

1. Исследование 14 образцов закупленного в торговой сети города Оренбурга чая позволило определить характеристики их элементного состава. Приведенные данные свидетельствуют о том, что уровни содержания эссенциальных и токсических элементов в товарных образцах чая различаются порой на порядковую величину и не зависят от вида чая.

2. Во всех образцах установленные СанПиН 2.3.2.1078-01 показатели предельно допустимого уровня содержания кадмия и свинца не превышены. Ртуть и мышьяк в образцах чая нами не обнаружены.

3. По результатам проведенного исследования не удалось выявить зависимость содержания танидов, флавоноидов и витамина С от сорта чая, но в ряде случаев рассчитана выраженная корреляция между содержанием тяжелых металлов и вышеперечисленных антиоксидантов в чае.

4. Содержание витамина С в образцах чая коррелирует с концентрациями хрома, кобальта и магния.

5. Уровень содержания флавоноидов в чае показывает положительную корреляцию с уровнем содержания кобальта и отрицательную - с содержанием кадмия.

6. Содержание танидов имеет слабую корреляцию со всеми исследуемыми элементами, кроме железа, с которым наблюдается положительная корреляция.

7. Концентрация меди в образцах чая не проявляет сколько-нибудь выраженной корреляции с исследуемыми низкомолекулярными антиоксидантами чая.

8. Учитывая высокую значимость чая как источника биологически активных веществ для населения России, следует проводить подробные исследования с целью выявления сортов чая с максимальным содержанием антиоксидантов.

\section{Список литературы}

1. Галиаскарова А.Р., Рахова К.М., Гатиатулина Е.Р. Проблема обеспечения витаминами населения Южного Урала и прилегающих территорий // Наука Красноярья. Биология. Экология. 2012. №5. С. 9-17.

2. Концепция государственной политики в области здорового питания населения Российской Федерации на период до 2005 года (Постановление Правительства Российской Федерации N 917 от 10 августа 1998 г.). База нормативных документов «КонсультантПлюс». URL: http://www.base.consultant.ru.

3. Распоряжение Правительства Российской Федерации о реализации второго этапа «Концепции государственной политики в области здорового питания населения Российской Федерации на период до 2005 года» (N 1891-p от 23 декабря 2003 г.). База нормативных документов «КонсультантПлюс». URL: http://www.base.consultant.ru.

4. Гусев Н.Ф., Петрова Г.В., Немерешина О.Н. Лекарственные растения Южного Урала (выращивание и использование). Оренбург, 2007. 358 с.

5. СанПиН 2.3.2.1290-03. Гигиенические требования к организации производства и оборота биологически активных добавок к пище (БАД). М., 2003. База нормативных документов «Консалтфарма». URL: http://www.consultpharma.ru.

6. Ефремов А.А., Макарова Л.Г., Шаталина Н.В., Первышина Г.Г. Минеральные вещества - основа снижения антропогенного воздействия окружающей среды на организм человека // Химия растительного сырья. 2002. №3. C. 65-68.

7. Немерешина О.Н., Шайхутдинова А.А. Оценка содержания тяжелых металлов в тканях Polygonum aviculare L. на техногенно загрязненных территориях // Экология и промышленность России. 2012. №9. С. 46-49.

8. Шленская Т.В., Шумкова И.А. Зеленый чай - полезный напиток для здорового питания // Инновационные технологии продуктов здорового питания: матер.VIII научно-практической конференции молодых ученых. М., 2010. C. 182-186.

9. МР 2.3.1.1915-04. Рациональное питание. Рекомендуемые уровни потребления пищевых и биологически активных веществ : методические рекомендации. База нормативных документов «RusGOST». URL: http://www.russgost.ru.

10. Драчева Л.В., Зайцев Н.К., Жарикова О.А. Антиоксидантная активность травяных чаев // Пищевая промышленность. 2011. №11. С. 32-34.

11. Кравченко Л.В., Трусов Н.В., Аксенов И.В., Авреньева Л.И., Гусева Г.В., Лашнева Н.В., Тутельян В.А. Влияние экстракта зеленого чая и его компонентов на антиоксидантный статус и активность ферментов метаболизма ксенобиотиков у крыс // Вопросы питания. 2011. Т. 80, №2. С. 9-15.

12. Татарченко И.И., Мохначев И.Г., Касьянов Г.И. Химия субтропических и пищевкусовых продуктов. М., 2003. $256 \mathrm{c}$.

13. Макарова М.Н., Макаров В.Г., Зенкевич И.Г. Антирадикальная активность флавоноидов и их комбинаций с другими антиоксидантами // Фармация. 2004. №2. С. 30-32. 
14. Мелкадзе Р.Г., Хвелидзе В.Г. Липофильный комплекс чайного листа // Химия растительного сырья. 2008. №4. C. $133-135$.

15. Шендеров Б.А., Доронин А.Ф. Чай и кофе основа для создания функциональных напитков и продуктов питания // Пиво и напитки. 2004. №2. С. 94.

16. Jung H.A., Jung M.J., Kim J.Y., Chung H.Y., Choi J.S. Inhibitory activity of flavonoids from Prunusdavidiana and other flavonoids on total ROS and hydroxyl radical generation // Arch. Pharm. Res. 2003. Vol. 26. Pp. 809-815.

17. ГОСТ 24027.2. Методы определения влажности, содержания золы, экстрактивных веществ, флавоноидов и дубильных веществ. База нормативных документов «RusGOST». URL: http://www.russgost.ru.

18. ГОСТ 30692-2000. Межгосударственный стандарт. Атомно-адсорбционный метод определения тяжелых металлов. Межгосударственный совет по стандартизации, метрологии и сертификации. Минск. База нормативных документов «RusGOST». URL: http://www.russgost.ru.

19. ГОСТ 2455.6-89. Метод определения аскорбиновой кислоты. База нормативных документов «RusGOST». URL: http://www.russgost.ru.

20. Ломбоева С.С., Танхаева Л.М., Оленников Д.Н. Динамика накопления флавоноидов в надземной части ортилии однобокой (Orthilia secunda (L.) House.) // Химия растительного сырья. 2008. №3. C. 83-88.

21. Немерешина О.Н., Трубников В.В., Гусев Н.Ф. Индукция синтеза антиоксидантов как механизм экоустойчивости травянистых растений степного Предуралья // Известия ОГАУ. 2011. №3(32-4). С. 274-276.

22. СанПиН 2.3.2.1078-01. Гигиенические требования безопасности и пищевой ценности пищевых продуктов. М., 2002. URL: http://www.base.garant.ru.

23. Chedeville O., Tosun-Bayraktar A., Porte C. Modeling of fenton reaction for the oxidation of phenol in water // J. Autom. Methods Manag. Chem. 2005. V. 2005. Pp. 31-36.

24. Song J.M., Lee K.H., Seong B.L. Antiviral effect of catechins in green tea on influenza virus // Antiviral Res. 2005. Vol. 68(2). Pp. 66-74.

25. Дополнение 1 к СанПиН 2.3.2.1078-01 «Гигиенические требования безопасности и пищевой ценности пищевых продуктов»: СанПиН 2.3.2.1153-02. М., 2003. // Российская газета. 2011. 20 апр.

26. Федеральный закон «О качестве и безопасности пищевых продуктов» (N 29-Ф3 от 02.01.00). База нормативных документов «КонсультантПлюс». URL: http://www.base.consultant.ru.

27. Cheng I.F., Breen K. On the ability of four flavonoids, baicalein, luteolin, naringenin, and quercetin, to suppress the Fenton reaction of the iron-ATP complex // BioMetals. 2000. Vol. 13. Pp. 77-83.

28. Ferguson P.J., Kurowska E.M., Freeman D.J., Chambers A.F., Koropatnick J. In vivo inhibition of growth of human tumor lines by flavonoid fractions from cranberry extract // Nutrition and Cancer. 2006. Vol. 56, N1. Pp. 86-94.

Поступило в редакиию 18 марта 2013 г.

После переработки 23 апреля 2013 г.

Nemereshina O.N..$^{*}$, Gusev N.F. ${ }^{2}$, Filippova A.V. ${ }^{2}$ CONTENTS OF TRACE ELEMENTS AND LOW-MOLECULAR ANTIOXIDANTS IN TEA

${ }^{\text {I}}$ Orenburg State Medical Academy, Sovetskaia st. 6, Orenburg, 460000 (Russia), e-mail: orgma@esoo.ru

${ }^{2}$ Orenburg State Agrarian universitet, Chelyuskintsev st. 18, Orenburg, 460014, (Russia), e-mail: orensau@mail.ru

This article presents the results of the analysis of trace elements ( $\mathrm{Cu}, \mathrm{Ni}, \mathrm{Mn}, \mathrm{Zn}, \mathrm{Mg}, \mathrm{Fe}, \mathrm{Cr}, \mathrm{Co}, \mathrm{Na}, \mathrm{Pb}, \mathrm{As}, \mathrm{Cd}, \mathrm{Hg}$ ) and antioxidants in the popular varieties and grades of tea. Significant differences in the levels, the elements in the samples of tea. Indicators of the maximum permissible level of cadmium and lead were not exceeded. Mercury and arsenic in samples of tea were found. The dependence is not the content of elements and antioxidants on the type and brand of tea. The correlation between levels of certain elements and antioxidants in tea and the necessity of a joint analysis of these parameters in the study of plants.

Keywords: tea, Thea sinensis L., antioxidants, flavonoids, tannin, ascorbic acid, trace elements and heavy metals.

\footnotetext{
* Corresponding author.
} 


\section{References}

1. Galiaskarova A.R., Rakhova K.M., Gatiatulina E.R. Nauka Krasnoiar'ia. Biologïa. Ekologiia, 2012, no. 5, pp. 9-17. (in Russ.).

2. Kontseptsiia gosudarstvennoi politiki v oblasti zdorovogo pitaniia naseleniia Rossiiskoi Federatsii na period do 2005 goda (Postanovlenie Pravitel'stva Rossiiskoi Federatsii $N 917$ ot 10 avgusta 1998 g.). [The concept of public policy in the field of healthy nutrition of the population of the Russian Federation for the period up to 2005 (Government Decree N 917 of 10 August 1998)]. URL: http://www.base.consultant.ru. (in Russ.).

3. Rasporiazhenie Pravitel'stva Rossiiskoi Federatsii o realizatsii vtorogo etapa «Kontseptsii gosudarstvennoi politiki v oblasti zdorovogo pitaniia naseleniia Rossiiskoi Federatsii na period do 2005 goda» (N 1891-r ot 23 dekabria 2003 g.). [Order of the Government of the Russian Federation on the implementation of the second phase of the «Concept of State Policy in the field of healthy nutrition of the population of the Russian Federation for the period till 2005» (N-p 1891 of 23 December 2003)]. URL: http://www.base.consultant.ru. (in Russ.).

4. Gusev N.F., Petrova G.V., Nemereshina O.N. Lekarstvennye rasteniia Iuzhnogo Urala (vyrashchivanie i ispol'zovanie). [Medicinal Plants of the Southern Urals (cultivation and use of either)]. Orenburg, 2007. 358 p. (in Russ.).

5. SanPiN 2.3.2.1290-03. Gigienicheskie trebovaniia k organizatsii proizvodstva i oborota biologicheski aktivnykh dobavok k pishche (BAD) [Sanitary rules and norms 2.3.2.1290-03 «Hygienic requirements for the organization of production and turnover of biologically active additives (BAA)»]. Moscow, 2003. URL: http://www.consultpharma.ru. (in Russ.).

6. Efremov A.A., Makarova L.G., Shatalina N.V., Pervyshina G.G. Khimiia rastitel'nogo syria, 2002, no. 3, pp. 65-68. (in Russ.).

7. Nemereshina O.N., Shaikhutdinova A.A. Ekologiia i promyshlennost' Rossii, 2012, no.9, pp. 46-49. (in Russ.).

8. Shlenskaia T.V., Shumkova I.A. Innovatsionnye tekhnologii produktov zdorovogo pitaniia: mater.VIII nauchnoprakticheskoi konferentsii molodykh uchenykh. [Innovative technologies of healthy foods: Materials VIII scientific conference of young scientists]. Moscow, 2010, pp. 182-186. (in Russ.).

9. MR 2.3.1.1915-04. Ratsional'noe pitanie. Rekomenduemye urovni potrebleniia pishchevykh i biologicheski aktivnykh veshchestv : metodicheskie rekomendatsii. [Guidelines 2.3.1.1915-04 "Nutrition. Recommended levels of food consumption and biologically active substances "]. URL: http://www.russgost.ru. (in Russ.).

10. Dracheva L.V., Zaitsev N.K., Zharikova O.A. Pishchevaia promyshlennost', 2011, no. 11, pp. 32-34. (in Russ.).

11. Kravchenko L.V., Trusov N.V., Aksenov I.V., Avren'eva L.I., Guseva G.V., Lashneva N.V., Tutel'ian V.A. Voprosy pitaniia, 2011, vol. 80, no. 2, pp. 9-15. (in Russ.).

12. Tatarchenko I.I., Mokhnachev I.G., Kas'ianov G.I. Khimiia subtropicheskikh i pishchevkusovykh produktov. [Chemistry subtropical and flavoring products]. Moscow, 2003, 256 p. (in Russ.).

13. Makarova M.N., Makarov V.G., Zenkevich I.G. Farmatsiia, 2004, no. 2, pp. 30-32. (in Russ.).

14. Melkadze R.G., Khvelidze V.G. Khimiia rastitel'nogo syr'ia, 2008, no. 4, pp. 133-135. (in Russ.).

15. Shenderov B.A., Doronin A.F. Pivo i napitki, 2004, no. 2, p. 94. (in Russ.).

16. Jung H.A., Jung M.J., Kim J.Y., Chung H.Y., Choi J.S. Arch. Pharm. Res., 2003, vol. 26, pp. 809-815.

17. GOST 24027.2. Metody opredeleniia vlazhnosti, soderzhaniia zoly, ekstraktivnykh veshchestv, flavonoidov $i$ dubil'nykh veshchestv. [State standard 24027.2 Methods for determination of moisture content, ash content, extractives, flavonoids and tannins]. URL: http://www.russgost.ru (in Russ.).

18. GOST 30692-2000. Mezhgosudarstvennyi standart. Atomno-adsorbtsionnyi metod opredeleniia tiazhelykh metallov. Mezhgosudarstvennyi sovet po standartizatsii, metrologii i sertifikatsii. [State standard 30692-2000. Interstate standard. Atomic-absorption method for the determination of heavy metals. Interstate Council for Standardization, Metrology and Certification.]. URL: http://www.russgost.ru (in Russ.).

19. GOST 2455.6-89. Metod opredeleniia askorbinovoi kisloty. [State standard 2455.6-89 Method for determination of ascorbic acid.]. URL: http://www.russgost.ru (in Russ.).

20. Lomboeva S.S., Tankhaeva L.M., Olennikov D.N. Khimiia rastitel'nogo syr'ia, 2008, no. 3, pp. 83-88. (in Russ.).

21. Nemereshina O.N., Trubnikov V.V., Gusev N.F. Izvestiia OGAU, 2011, no. 3(32-4), pp. 274-276. (in Russ.).

22. SanPiN 2.3.2.1078-01. Gigienicheskie trebovaniia bezopasnosti i pishchevoi tsennosti pishchevykh produktov. [Sanitary rules and norms 2.3.2.1078-01 "Hygienic requirements for safety and nutritional value of food products"]. Moscow, 2002. URL: http://www.base.garant.ru (in Russ.).

23. Chedeville O., Tosun-Bayraktar A., Porte C. J. Autom. Methods Manag. Chem., 2005, vol. 2005, pp. 31-36.

24. Song J.M, Lee K.H, Seong B.L. Antiviral Res., 2005, vol. 68(2), pp. 66-74.

25. Dopolnenie 1 k SanPiN 2.3.2.1078-01 «Gigienicheskie trebovaniia bezopasnosti $i$ pishchevoi tsennosti pishchevykh produktov»: SanPiN 2.3.2.1153-02. [Appendix 1 to Sanitary rules and norms 2.3.2.1078-01 "Hygienic requirements for safety and nutritional value of food products": Sanitary rules and norms 2.3.2.1153-02.]. Moscow, 2003. (in Russ.).

26. Federal'nyi zakon «O kachestve i bezopasnosti pishchevykh produktov» (N 29-FZ ot 02.01.00). [Federal Law "On the quality and safety of food products» (N 29-FZ of 02.01.00)]. URL: http://www.base.consultant.ru (in Russ.).

27. Cheng I.F., Breen K. BioMetals, 2000, vol. 13, pp. 77-83.

28. Ferguson P. J., Kurowska E. M., Freeman D. J., Chambers A. F., Koropatnick J. Nutrition and Cancer, 2006, vol. 56, no. 1, pp. 86-94. 